\title{
SOCIALVETENSKAPLIGA KLASSIKER
}

\section{Vad kan vi lära av Harry Martinsons författarskap?}

\author{
HANS SW $\ddot{A} R D$
}

Socialvetenskaplig tidskrift vill uppmärksamma 100-årsjubileet av Harry Martinsons födelse. Han har bl.a. med egna erfarenheter som grund skildrat fattig-Sverige och hur livet kunde te sig för utsatta människor decennierna efter förra sekelskiftet. Vad kan dagens samhällsvetare lära sig av Martinson?

I år är det hundra år sedan den svenske författaren Harry Martinson föddes. Hundraårsjubileet har uppmärksammats runt om $\mathrm{i}$ landet. Nobelmuseet har haft en Martinsonutställning. Litteraturvetare har ordnat symposier och diskuterat och analyserat Martinsons litteratur. De litterära tidskrifterna har innehållit initierade artiklar. Vår systertidskrift Tvärsnitt har i nummer 2/2004 Harry

Hans Swärd är professor i socialt arbete vid Socialhögskolan, Lunds universitet.
Martinson som tema. Trots att han saknade akademisk utbildning lyckades han, enligt tidskriften, på ett föredömligt sätt fungera som en brygga mellan humaniora och naturvetenskap. Martinsons tragiska barndom har ofta lyfts fram vilket bl.a. belyses i Teater Nostras pjäs "Den siste Vikingen« som hade premiär under jubileumsåret.

Gunvor Andersson, Per Gunnar Edebalk, Ove Mallander och Anna Meeuwisse har läst texten och kommit med värdefulla synpunkter. Ett stort tack! 
Det är alltså många som visat intresse för författaren. Också det socialvetenskapliga forskningsfältet har skäl att uppmärksamma Martinson. Hans livsöde och litterära beskrivningar berör många av de problem och frågeställningar som forskningen i dag är sysselsatt med. År 2003 gav Socialvetenskaplig tidskrift ut ett nummer om "Svensk välfärd under 100 årı. Forskare från olika discipliner beskrev den svenska välfärdens utveckling från 19032003. Med ledning av beskrivningarna kan vi dra slutsatsen att både Martinsons och hans romanfigurers livsöden i många avseenden har starka beröringspunkter med den nordiska välfärdsstatens framväxt och utveckling. Martinson har med egna upplevelser som grund, men med diktarens frihet, belyst villkoren för dem som kom i kontakt med samhällets hjälp- och kontrollsystem i fattigSverige. Han gjorde en unik karriär från fattighjon och sockenunge till akademiledamot och nobelpristagare. Som ung pojke var han också barnhemsbarn på barnhemmet Timmermansplatsen i Majorna i Göteborg, efter att under en rymning från ett fosterhem ha hittats av en tjänsteman på barnavårdsnämnden. Under perioder av senare arbetslöshet tar han in på olika ungkarlshotell, tigger, luffar och livnär sig på kyrkornas soppkök. Det är också som hemlös på ett av ungkarlshotellen i Göteborg som han en sömnlös natt fick en impuls att börja skriva. ${ }^{1}$ Efter en halv mans-

1 Uppgifterna hämtade från numret Harry Martinson special, Zenit, Kulturtidningen i väst 2004 „Från tiggare till hedersdoktor. Harry Martinsons liv i Göteborg». Med hänvisning till Sonja Erfurths biografier över Martinson tror man att det kan ha gällt ungkarlshotellet Labor på Mellangatan eller natthärbärget Skanstorget. ålder återkom han 1954 till de gator som han tiggt på i Göteborg för att promoveras till hedersdoktor. Göteborgs högskola hade just omvandlats till universitet och den tidigare hemlöse tiggaren blev universitetets första hedersdoktor. Kanske är hans liv en illustration till den svenska välfärdsdrömmen, som i många avseenden kanske bara blev en dröm eftersom vi fortfarande har både moderna "sockenungar" och hemlösa i vår välfärd. Kan då dagens välfärdsforskare lära något av Martinsons författarskap?

Romanfiguren Martin i de självbiografiska böckerna får om och om igen under sin sockenvandring den lägsta kaststämpeln, "fattighjonet", djupt inpräntad i sig. Kärlekslösheten och de vuxnas ointresse är ett återkommande tema. "Jag minnes en mun, som aldrig log mot mig» skriver Martinson. Barndomens höjdpunkt var den säregne läraren Staaf, en nyckelperson i Martins liv, en berättare och en vuxen som tog barnen på allvar. Martin längtade till skolan, geografin och planscherna. I sin älskade skola drömde han sig bort från fosterhemmens kyla och tystnad.

Romanfiguren luffaren Bolle i en av Martinsons andra böcker står vid sidan av samhället. Förnedringen och förödmjukelserna är alltid närvarande. "Låt dig aldrig luras att se ner på de svaga« blir Bolles livsfilosofi. Luffar- och hemlöshetslivet innebar ingen frihet, bara rädslan för att omhändertas och straffas för lösdriveri.

Böckerna väcker många frågor om insider- och outsidersproblematiken och relationerna till de svaga i samhället. De handlar om myter och föreställningar, om en kategoriserings- och gränsdragningsproblematik. Också relationer mellan olika etniska 
grupper belyses i sjömanstexterna och förhållandet mellan det västerländska och det från ett europeiskt perspektiv främmande och annorlunda. Kanske kan Martinsons romanfigurer fungera som guider för att ge ett litet annorlunda perspektiv för att förstå den utsatta människan i vår socialhistoria.

I de båda självbiografiska böckerna Nässlorna blomma och Vägen ut samt luffarromanen Vägen till Klockrike är alltså Martin och Bolle huvudpersonerna. Ett övergivet barn som behövde samhällets skydd och en kringvandrande hemlös luffare som samhället försökte skydda sig mot. De kan åskådliggöra två sidor av den skandinaviska välfärdsmodellen, nämligen å ena sidan hjälp och omhändertagande och å andra sidan kontroll och tvång, en paradox som också är inbyggd i det sociala arbetets historia i Norden. ${ }^{2}$

Låt oss försöka placera in sockenungen och luffaren i en socialvetenskaplig kontext genom att göra några nedslag i den svenska socialhistorien under 1900-talets första decennier och i den moderna socialhistoriska forskningen som behandlar denna tidsperiod.

\section{Ett författarliv}

Eftersom Martinson med egna upplevel-

2 Frågan om förhållandet hjälp och tvång har under senare tid varit ett tema i nordisk välfärdshistorisk forskning. Klas Åmark (2004) har nyligen gjort en översikt av denna forskning. I ett stort antal komparativa studier behandlas välfärdsstatens framväxt och utveckling och tvånget har ofta under senare decennier analyserats utifrån ett Foucault-inspirerat forskningsperspektiv. ser som grund, men med diktarens frihet, belyst hur livet kunde gestalta sig för de utsatta kan det finnas skäl att inledningsvis belysa hans egen livshistoria. ${ }^{3}$

Den 6 maj 1904 föddes Harry Martinson i Nyteboda, i Blekinge. Föräldrarna var lanthandlaren Martin Olofsson och Bengta som senare antog namnet Betty. Martin är femte barn av sju och ende sonen. Åren 1910 och 1911 drabbades föräldrarna, som drev handelsbod i Nyteboda, av flera stora katastrofer som helt kom att förändra Harrys liv. Fadern som tidigare hade rest och arbetat i olika länder var ofta frånvarande under sonens barndom. Han vistades i USA 1905-1908 och var också under denna tid påmönstrad på en kanadensisk boskapsbåt. Mot slutet av sitt liv avtjänade han ett nio månaders fängelsestraff. När han frigavs var han märkt av sin tbc och dog kort därefter 1910, 41 år gammal. Modern Betty blev änka vid 34 års ålder och hade 7 barn att dra försorg om. Redan under Martins fängelsevistelse gick handelsboden i konkurs. Betty flyttade och startade en matservering i det närbelägna samhället Gylsboda där brytning av svart granit var en storindustri i början av 1900-talet och lockade många stenarbetare som inlogerades i samhället. Familjeekonomin förbättrades knappast genom familjens flyttning från Nyteboda, utan försämrades tvärtom successivt. Det

3 Beskrivningen i detta avsnitt bygger på biografin som presenteras på Harry Martinson- Sällskapets hemsida: http://www.harrymartinson. org/biograph.htm samt på länken Nordic Authors http://www.lysator.liu.se/runeberg/authors/hmartins.htm, samt Sonja Erfurths (1980, 1991) biografiska böcker om Harry Martinson. 
var svårt för modern att sköta både familj och matservering. När hon dessutom blev gravid ytterligare en gång och skulle föda ett utomäktenskapligt barn beslöt hon sig för att emigrera till staden Portland i USA, där Martin en gång arbetat och sade sig ha en försäkring att hämta. I slutet av graviditeten reste hon till Göteborg för att föda sitt åttonde barn, Tore, som hon lämnade till utackordering innan hon lämnade Sverige för gott.

Bettys halvsyster tog tillfälligt hand om den stora kvarlämnade barnaskaran, men kunde inte göra det i längden utan lämnade till slut över barnen till fattigvården. Det kom att leda till en långvarig process om hemortsrätten eftersom familjen hade flyttat från Jämshögs till Örkeneds kommun och ingen av kommunerna ville ta hand om barnen utan hänvisade till varandra. Till slut dömdes Jämshög att ta emot dem. Syskonen skingrades och placerades i olika fosterhem. Harry placerades hos Åbon Nils Svensson i Gillesnäs mot 5 kronor i månaden. Sammanlagt var han placerad i fem fosterhem och under två år på fattighuset i Jämshög. Det finns många vittnesmål om att livet för syskonen präglades av vanvård, svält, förnedring och ständiga förflyttningar.

Harry hade aldrig mer kontakt med modern, som dock senare tog över dottern Klara Eugenia till USA. Ytterligare en dotter, Blenda Elvira, tog sig över till modern med egna pengar.

När fattigvården hade fullgjort sitt uppfostringsansvar och Harry fyllt 16 år tog han värvning vid skeppsgossekåren i Karlskrona. Han straffade dock ganska snabbt ut sig. Under 1920-talet arbetade han som eldare på flera större båtar och luffade på olika kontinenter. När han drabbades av tbc fick han lämna sjömanslivet. Han började istället publicera dikter i tidningarna och 1929 kom samlingen Spökskepp. Med Nomad, två år senare, fick han sitt genombrott. I tät följd gav han nu ut Resor utan mål och Kap Farväl. 1929 gifte sig Harry med den 37-åriga fembarnsmodern Helga Maria Johansson, född Schwartz som nu blev Moa Martinson.

Barndomsskildringarna Nässlorna blomma (1935) och Vägen ut (1936) beskriver huvudpersonen Martin Tomassons utveckling fram till dess han går till sjöss som sextonåring. Många bedömare har menat att Martinson haft en unik förmåga till inlevelse i barnets värld och på ett autentiskt sätt kunnat skildra en svår uppväxt. Harry Martinson har själv framhållit att hans böcker inte är socialhistoriska reportage om fattigSverige kring 1900 utan litterära konstverk som inte alltid är exakta verklighetsbeskrivningar. Under 30-talet kom också Svärmare och harkrank (1937), Midsommardalen (1938) och Det enkla och det svåra (1939). 1940 skiljde sig Moa och Harry. Samma år gick Martinson som frivillig ut i finska vinterkriget. Han skrev Verklighet till döds (1940) och Den förlorade jaguaren (1941). 1942 gifte sig Harry med Ingrid Lindcrantz. Deras äktenskap varade livet ut. De fick två döttrar. Diktsamlingen Passad kom ut 1945. Till prosan återvände han i Vägen till Klockrike (1948). Huvudperson är den f.d. cigarrmakaren Bolle som senare blir luffare. 1949 invaldes Martinson som efterträdare till Elin Wägner i Svenska Akademien, som den förste självlärde författaren.

Under 50-talet följde Cikada (som 
bland annat innehöll de första Aniarasångerna) och 1956 så hela Aniara, som innebar hans internationella genombrott. År 1954 utnämndes han, som tidigare nämnts, också till hedersdoktor i samband med invigningen av Göteborgs universitet. Senare titlar är Vagnen (1960), Utsikt från en grästuva (1963), Dikter om ljus och mörker (1971) och Tuvor (1973). 1974 tilldelades han nobelpriset i litteratur tillsammans med Eyvind Johnson.

Lars Gyllensten (2000) berättar i sina memoarer om hur Harry Martinsons sista tid i livet förmörkades av den kritik som riktades mot honom. Hans språk betraktades som svårt och hans idéer tycks inte ha passat in i tidsandan. Det ansågs fel av Akademien att prisbelöna sina egna och det talades om akademisk korruption och kamaraderi. Gyllenstens tes är att Martinson aldrig kom över angreppen och nålsticken utan att de drev honom in i en depression som till slut resulterade i självmord. Gyllenstens tes har inte fått stå oemotsagd. Representanter för Dagens Nyheters, Aftonbladets och Expressens kulturredaktioner har hävdat att Martinsons reaktion var överdriven och någon menade t.o.m. att den hade drag av paranoida inbillningar.

\section{Martin och Bolle vid förra sekelskiftet}

I de båda delvis självbiografiska böckerna Nässlorna Blomma och Vägen ut skildrar Martinson villkoren för ett "föräldralöst" barn som måste tas om hand av fattigvården i fattig-Sverige. Romanen Vägen till Klockrike handlar om luffaren Kristofer Teodor Bolle, en person som ansågs samhällsfarlig och som samhället ville skydda sig emot. Boken tar sin utgångspunkt i 1800-talets industriella omvandling. Bolle är cigarrmakare när vi först möter honom - ett yrke att vara stolt över och som ger en känsla av utvaldhet. Handcigarrmakarna besatt de romantiska yrkenas högmod. Yrket var förbundet med de rikas och förnämas liv, finsmakarnas levnadskonst, tankar och kontemplationer.

Berättelsen om Bolle börjar i februari månad 1898. Vid denna tid drogs grunden undan för en hel yrkeskår. Cigarrmakarna byttes ut mot maskiner. Cigarrer skulle ersättas av maskintillverkade cigaretter. Den hantverksskicklighet som cigarrmakarna under många år tränat upp var plötsligt inget värd.

Bolle blir luffare på vandring genom Sverige. Det innebär att han ger upp sådant som skapar trygghet: arbete, hem och familj. Han sover ofta i lador eller under bar himmel. Han sällar sig till de hemlösa luffarnas skara.

Som luffare blir Bolle förnedrad och bespottad. Han utsätts för fysiskt våld och omhändertas för lösdriveri. Den ena gången döms han till tvångsarbete $i$ ett helt år. Trots fattigdom och förnedring är Bolles frihetskänsla så stor att han fortsätter att vandra på vägarna. I bokens sista del drabbas Bolle av tbc och tas in på sanatorium, där han dör.

Hur såg då situationen ut för Martin och Bolle vid förra sekelskiftet och hur såg mötet ut med samhällets omsorg och repression? Någon generell socialpolitik fanns inte vid denna tid. Martin behandlades enligt 1871 års fattigvårdsförordning, Bolle enligt 1885 års lösdriverilag. 


\section{1 års fattigvårdsförordning}

1871 års fattigvårdsförordning kunde ge viss hjälp till bestämda grupper. I förhållande till tidigare lagstiftning innebar den dock en försämring för den enskilde och bl.a. avskaffades besvärsrätten. Per Gunnar Edebalk (2003) menar att det är oklart om förordningen i praktiken överhuvudtaget gav den enskilde rätt till understöd även om lagen stadgade en sådan rätt. Någon statlig kontroll över verksamheten fanns inte och det är uppenbart att det fanns stora missförhållanden. Socialstyrelsen tillkom 1912 och socialdepartementet 1920 vilket gjorde att kontrollen efterhand kunde förbättras något. Först 1918 fick vi i Sverige en modern fattigvårdsförordning.

Ett grundläggande tema i förordningen från 1871 var en självförsörjningsprincip som gick ut på att alla arbetsföra var skyldiga att försörja sig själva och sina minderåriga barn. Fattigvårdslagstifningskommittén som föregick lagen skriver "Föräldrar äro pliktiga att utan fattigvårdssamhälles betungande försörja sina minderåriga barn" (SFS 1918:422 §2). »Min far är död och min mor är i Kalifornien«, så beskriver Martin sin utsatthet. Han hade helt enkelt ingen som kunde försörja honom och ingen som lagens krav kunde riktas mot. Därför var han en av dem som kunde räkna med omhändertagande och försörjning enligt förordningen eftersom minderåriga utan försörjning skulle hjälpas. Martin pekar dock på många missförhållanden i fosterhemmen och i samhällsdebatten framhölls ofta att fattigvårdsförordningen var otidsenlig vilket ofta visade sig särskilt i småkommunerna.
Omkring 70 procent av befolkningen bodde på landsbygden vid förra sekelskiftet. Totalt fanns mer än 2400 kommuner. De flesta var små och kunde själva utforma sin fattigvård. Fattigvården finansierades med lokala skatter och för många småkommuner på landsbygden var fattigvårdsutgifterna betungande och man hade helt enkelt svårigheter att klara dem. Enligt Edebalk (2003) var det detta som i hög utsträckning bidrog till missförhållandena på området. Strider om hemortsrätten, dvs. vem som skulle betala, var inte ovanliga. Ända fram till 1918 användes fyra fattigvårdstekniker i många kommuner. Utackordering innebar att människor som behövde försörjning utackorderades i andras hem, bortauktionering innebar att den som krävde lägst ersättning från kommunen (d.v.s. ofta andra fattiga fick ta hand om den fattige), rotegång innebar att de som behövde hjälp enligt ett roterande schema mottogs för försörjning bland rotens medlemmar samt anstalter (fattigstugor, fattighus och fattiggårdar) i vilka olika slags understödstagare blandades (Edebalk 2003). Enligt Mikael Sjögren (1997) var bortauktionering till lägstbjudande det som undantagslöst ansågs mest förnedrande. Förutom att bli bortauktionerad vistades Martin på fattighuset i Jämshög under två år tillsammans med de äldre fattighjonen. I samhällsdebatten kritiserades ofta att olika kategorier blandades på fattighusen och särskilt att barn blandades med äldre som genom sin bristande moral kunde inverka negativt på de ofördärvade. Martin trivdes emellertid bättre på fattighuset än som fosterbarn hos bönderna. 


\section{5 års lösdriverilag}

Någon hjälp enligt 1871 års fattigvårdsförordning fick inte Bolle så vitt man kan utläsa. Det är inte heller sannolikt att ensamstående män i yrkesverksam ålder fick någon hjälp. Att försörja sig på tiggeri sågs som demoraliserande. Men det fanns en stor dubbelhet $\mathrm{i}$ inställningen vid denna tid, man sa en sak och gjorde en annan. Det var inget specifikt nordiskt fenomen utan samma dubbeltydighet fanns i flera industrialiserade länder, ett förhållande som bl.a. lyfts fram av den amerikanske forskaren Kim Hopper (1987, 1990, 1991, 1992). Enligt Hopper började man i den allmänna debatten i USA i slutet av 1800-talet att identifiera en mer aggressiv grupp hemlösa luffare i de större städerna. Vetenskapligt inriktade välgörenhetsorganisationer började kräva sociala åtgärder för de hemlösa. Tidigare hade polisen omhändertagit de hemlösa luffarna i arrester, fängelser och på tvångsinstitutioner, men de började nu i mindre utsträckning att ses som en polisiär fråga. De offentliga härbärgena kom att ersätta polisstationer och fängelser som övernattningsinstitutioner. Det allmänna kunde inte längre ignorera de stora skaror hemlösa som drogs till städerna i perioder av ekonomisk depression.

I svåra tider räckte inte härbärgesplatserna till utan en del hemlösa fick sova i korridorerna i polishuset och t.o.m. i stadshuset i Chicago. Under goda ekonomiska tider sjönk behovet av härbärgesplatser. Det innebar stora svårigheter att parera tillgången på härbärgesplatser till en fluktuerande efterfrågan. Härbärgessystemet kom att fungera som en buffert för de cykliska förhållanden på arbetsmarknaden som den tidiga industrialismen skapade. Poängen är emellertid att det fanns en stor dubbelhet i om man skulle hjälpa luffare och hemlösa eller ej.

En liknande diskussion fick vi i Sverige i samband med införandet av den nya lösdriverilagen som innebar att det gamla försvarslöshetssystemet avskaffades. Skepsisen mot arbetslösa har gamla anor. Begreppet laga försvar hade sina rötter i tjänstehjonstadgan på 1500-talet och kom senare att beteckna dem som inte hade fast arbete eller förmögenhet. I början av 1800-talet togs många försvarslösa in på tvångsarbetsanstalter, spinnhus, fängelser och fästningar där de fick stanna tills de lyckades få en tjänst. Försvarslöshetssystemet avskaffades först 1885, efter en omfattande debatt och stora motsättningar. De gamla jordägarna ville ha kvar den traditionella försvarslöshetslagstiftningen som man trodde skulle förhindra en allt för stor rörlighet, medan de nya industriägarna var mer positiva till en lättrörlig arbetskraft. Utbyggnaden av järnvägssystemet, behovet av säsongsarbetskraft i städerna osv. krävde en arbetskraftsreserv som var lättillgänglig. I den nya lösdriverilagen räckte det inte med att någon var arbetslös utan man skulle också vara samhällsfarlig för att kunna dömas till tvångsarbete.

Det var alltså 1885 års lösdriverilag som gällde när Bolle gick på luffen. Enligt denna lag kunde den som »stryker omkring utan att söka ärligen försörja sig och tilllika företer ett sådant levnadssätt att våda därav uppstår för allmän säkerhet, ordning och sedlighet« av länsstyrelsen dömas till tvångsarbete. De mest kända tvångsarbets- 
anstalterna var Svartsjö för män och Landskrona citadell för kvinnor. De kvinnor som dömdes var ofta prostituerade och männen som dömdes uppvisade ofta ett beteende som uppfattades som störande utan att därför var direkt brottsligt.

I samband med den nya lagens tillkomst krävde många filantroper också i Sverige att samhället skulle ta ett större ansvar för hemlösa, luffare och tiggare. 1885 föreslogs t.ex. att fattigvårdsnämnden i Stockholm borde öppna härbärgen för hemlösa och tiggare. Det fanns också de som pläderade för att de hemlösa i första hand skulle behandlas av fattigvården och inte längre enligt lösdriverilagstiftningen. Det var inte lika självklart som tidigare att fattiga och hemlösa människor skulle ses som ett fångvårdsproblem (Swärd 1998).

Flera frivilligorganisationer öppnade också vid denna tid härbärgen i storstäderna för husvilla. Men också bland dessa organisationer fanns en dubbel inställning och inte heller de många filantropiska föreningarna som fanns vid denna tid skulle självklart lämna någon hjälp till Bolle. ${ }^{4}$ Man hade, som i samhället i övrigt, allt-

4 På senare tid ett flertal forskare behandlat filantropins roll decennierna runt förra sekelskiften. Som exempel kan nämnas Staffan Förhammars (2000) bok Med känsla eller förnuft? Svensk debatt om filantropi 1870-1914, Frans Lundgrens (2003) avhandling Den isolerade medborgaren. Liberalt styre och uppkomsten av det sociala vid 1800-talets mitt, Marika Hedins (2002) avhandling Ett liberalt dilemma: Ernst Beckman, Emilia Brommé, C H von Koch och den sociala frågan 1880-1930 och Mikael Sjögren (1997) Fattigvård och folkuppfostran. Liberal fattigvairdspolitik 1903-1918. mer börjat skilja på värdiga och ovärdiga fattiga. De ovärdiga fattiga var sådana som själva ansågs ha orsakat sin fattigdom genom att underlåta att ärligen försörja sig genom lättja, missbruk osv. Umeåhistorikern Mikael Sjögren (1997) menar att oförskyllt arbetslösa inte automatiskt räknades som värdiga fattiga. Ofta sågs arbetslösheten som ett individuellt problem och man menade att den som verkligen ville ha ett arbete också kunde få det. Dessutom var det som jag skall återkomma till stor skillnad mellan stad och land. Ett förhållande som Edebalk (2003) tydligt framhållit och som ofta försummats i tidigare forskning.

Härbärgen och filantropiska organisationer var en storstadsföreteelse. Eftersom Bolle ofta vandrade på landsbygden, var det tvånget i lösdriverilagen som blir mest påtagligt. Det var samhällsskyddet som kom i främsta rummet i lagen, men det fanns också en tanke om att arbetsovilliga människor skulle kunna förbättras genom hederligt och hårt arbete. Man ville förbättra moralen och förhindra lättja och osedlighet. Så här beskriver Martinson tvångsarbetet $\mathrm{i}$ boken Vägen till Klockrike:

Berget kallade luffarna den anstalt dit de fördes då de dömts till tvångsarbete för att de hade tiggt och gått landsvägar. /... Tre gainger stod Bolle i Berget, men blev inte annorlunda därav.

\section{Hjälpoch tvång}

Hur såg man då vid denna tid på relationen mellan hjälp och tvång. Det fanns sannolikt, som redan tidigare konstaterats, en dubbel inställning till kringvandrande människor 
som både ett hot och möjlighet, vilket bl.a. återspeglas i Georg Simmels berömda essä "Främlingen" från 1908 (jämför också t.ex. Järvinen 2003). Överhuvudtaget började synen på de lägre klasserna att förändras. Medborgerliga fri- och rättigheter diskuterades även för de sämst ställda. Men samtidigt som man ville ge människor medborgerliga rättigheter, började paradoxalt nog en rad nya tvångslagar att diskuteras. Flera forskare har analyserat det »vårdtvång« som tillkom eller fanns vid förra sekelskiftet. Det gäller t.ex. historiken Jenny Björkman i avhandlingen (2001) Vard för samhällets bästa. Debatten om tvaingsvård $i$ svensk lagstiftning 1850-1970 som behandlar flera av de sociala tvångslagar, som fanns vid förra sekelskiftet. Johan Edman (2004) har i avhandlingen Torken. Tvaingsvaird av alkoholmissbrukare i Sverige 1940-1981, behandlat en senare tidsperiod av den tvångslag för alkoholister som tillkom 1913. Alkoholister som låg samhället till last eller uppträdde störande kunde placeras på anstalt. Temat berörs också indirekt i Anna Jansdotters (2004) avhandling Ansikte mot ansikte. Räddningsarbete bland prostituerade kvinnor $i$ Sverige 1850-1920, som bl.a. behandlar reglementeringen som 1859 blev officiellt sanktionerad och användes fram till 1918. Reglerna innebar att prostituerade tvingades registrera sig hos polisen och de övervakades och ålades att uppsöka läkare för besiktning. Bröt de mot lagen kunde de dömas till tvångsarbete. År 1903 infördes ett vårdtvång i barnavårdslagarna (se t.ex. Lundström 1993, Sundkvist 1994, Levin 1998).

Utifrån sett kan Martin och Bolles situation te sig ganska annorlunda. Den ene behandlades med ett öppet tvång, den andre skulle beskyddas. Men frågan är om skillnaden var så stor. Senare barnforskning har visat att man ofta inte vare sig då eller nu tar reda på vad barnen själva tycker. Det är föräldrar eller samhällets representanter som bestämmer. Jenny Björkman (2001) som på djupet undersökt tvångsvård i svensk lagstiftning 1850-1970 menar att "nästan all vård av barn kan definieras som tvångsvård eftersom det sällan spelar någon roll vad barnen själva tycker» (a.a. s. 15).

\section{De utsatta i samhällsdebatten}

Martin och Bolle tillhörde de grupper av utsatta människor som började tilldra sig ett större intresse i samhällsdebatten i slutet av 1800-talet. Det gällde t.ex. barnens situation, de ensamstående mödrarna och de ensamstående fattiga männen som tiggde, missbrukade eller vagabonderade.

I grunden låg debatten om den sociala frågan och en önskan om att förbättra förhållandena. Det utvecklades också en socialrealistisk tradition i journalistik, litteratur och vetenskap (Wisselgren 2003). En bättre tryckeriteknik och ett nytt sätt att beskriva sociala problem bidrog till detta. På 1870-talet började man t.ex. med fotografins hjälp att dokumentera fattiga individer, kriminella, utsatta barn, hjälpbehövande sjuka, koloniserade folk och arbetare enligt den engelske konsthistorikern John Tagg (1988 s. 83). Vanliga objekt för porträttering av nöd var utsatta människor som vi har lätt att känna medlidande med eller som lockar till skuldkänslor (Swärd 2001). Två sådana grupper har ibland lite tillspetsat sammanfattats under begreppen "det 
gråtande barnet" och "trashanken«. Den ena gruppen handlar om utsatta barn och den andra om mycket fattiga människor, t.ex. hemlösa, luffare, vagabonder och tiggare. Det har naturligtvis förekommit bilder på fattiga människor tidigare i historien, men nu när beskrivningarna ingick i det borgerliga uppfostringsprojektet kom de att få stor genomslagskraft och påverkade synen på fattiga människor (se t.ex. Himmelfarb 1984, Tagg 1888, Gordon 1989).

\section{De hemlösa männen}

Hemlösa tiggare blev alltså objekt i samhällsdiskussionen på ett helt annat sätt än tidigare i slutet av 1800-talet och framför allt inriktade sig många på de härbärgesmiljöer som höll på att växa upp i storstäderna. Bildkonstnären George Cruikshank (17921878) avbildar en sovsal på ett av de härbärgen, som växte fram i storstäderna som ett svar på industrialismens bostadsbrist. ${ }^{5}$ Den kom att bilda upptakten till en omfattande kritik mot storstädernas enklare natthärbärgen. Den kände dansk-amerikanske fotografen Jacob August Riis (1849-1914) - som själv tidvis var både arbets- och bostadslös i New York - upprördes bl.a. över situationen på de s.k. polishärbärgena. Erfarenheterna skildrar han t. ex. i boken How the Other Half Lives (1890). Riis' fotografier och förbindelser med USA:s blivande president lär bl.a. ha lett till att härbärgessystemet reformerades. Maksim Gorkijs skådespel Natthärbärget (1903) är ett annat exempel på hur härbärgesmiljöerna lockade till

5 Flaskan och drinkarens barn i 16 tavlor, tecknade och etsade av Cruishank (1907). dramatiska beskrivningar. Härbärgen blev också objekt för förra sekelskiftets sociala kartläggare och många av dessa beskrivningar räknas i dag som klassiker på området. Det gäller t.ex. Knut Tengdahls undersökning av härbärgesmiljöer i Stockholm från 1897. Tengdahl var journalist och ordförande i hamnarbetarnas fackförening när undersökningen genomfördes. Omkring en femtedel av de hamnarbetare som 1895 var medlemmar i Hamnarbetarfackföreningen hade uppgivit adresser till härbärgen och logihus. Tengdahl ville ta reda på hur livet gestaltade sig på de sämre härbärgena och gjorde oanmälda besök på nätterna och dokumenterade noggrant sina observationer. Ett annat exempel är »1912-års män«. Murarförmannen Fahlberg tog initiativet. Han samlade en tolvmannagrupp bestående av samhällsintresserade män som representerade olika samhällsklasser och skilda yrken. Undersökarna ville beskriva situationen på de ungkarlshotell och natthärbärgen som hade vuxit upp för att mildra den värsta bostadsnöden. I samhällsdebatten hävdades att privata intressen slog mynt av situationen, utnyttjade de husvilla och lät dem bo under odrägliga förhållanden. Initiativtagarna till aktionen ville också påverka den allmänna opinionen och få samhället att förbättra förhållandena (Alfvén 1913).

\section{De utsatta barnen}

Både av befolkningspolitiska skäl och skäl som hade att göra med industrialismens utveckling, intresserade sig många speciellt för barns villkor vid förra sekelskiftet. Ellen Keys (1900) proklamationer om 1900- 
talet som »barnets århundrade» innebar att hon argumenterade för att barn skulle uppfostras med moderna pedagogiska metoder, sysselsättas i föreningar och söndagsskolor. I Amerika började "The Child Study Movement« att utvecklas och presenterade nya vetenskapliga rön om barnens situation, resultat som ivrigt diskuterades bland medelklassen (Ross 1972:279 ff). De lagar som började tillkomma decennierna runt sekelskiftet föregicks också ofta av en offentlig diskussion. Det stiftades i slutet av 1800-talet lagar kring barnarbetet i bl.a. fabrik och hantverk efter ett flertal utredningar och undersökningar. Fosterbarnens ställning uppmärksammades i fosterbarnskommitténs förslag som blev lag 1902. Vid sekelskiftet var "fosterbarnsvården" en oreglerad och vildvuxen verksamhet. Vi hade i slutet av 1800-talet haft en diskussion om änglamakeriet, dvs. att en del kvinnor, framför allt i storstäderna, tog emot barn som vanvårdades och i en del fall dog. 1902 års lagar om fosterbarnsvård reglerade verksamheten något och fattigvården blev nu skyldig att bättre kontrollera de hem som användes som fosterhem. Det kom dock ständiga klagomål på att verksamheten fungerade dåligt och att kommunerna inte utförde sin kontroll. Martin var ju också mycket kritisk till en del av de fosterhem han vistades $i$.

Ett stort intresse visades barnadödligheten, de utomäktenskapliga barnens situation och de ensamstående mödrarna. För Martin är det en tragedi att hans mor har lämnat honom och att han måste uppfostras i olika fosterhem. Mödrarnas situation stod ofta också i fokus i samhällsdebatten vid förra sekelskiftet. De filantropiska föreningarna hade vid 1800-talet utvecklat en moders- eller hemideologi. Genom hemmet skulle många av de nya samhällsproblemen få sin lösning. Ansvaret lades på kvinnorna. Det var samtidigt som kvinnorna kämpade om rösträtt och medborgerligt anseende. Fattiga kvinnor, inte minst på landsbygden, levde ett hårt liv. De hade lägre lön än männen och kunde lätt hamna i en hopplös situation. Många hade vid denna tid lämnat fattiglandet Sverige för att söka en ny framtid i framtidslandet USA. Också Martins mor lämnade sina barn och flyttade dit. En bidragande orsak till att Harry Martinsons egen mor lämnade barnen och utvandrade var att hon hade svårt att försörja sig och att hon som änka blev gravid utan att vara gift. Riksdagen beslöt att införa en allmän pensionsförsäkring 1913, dvs. några år efter det att Betty utvandrat. Hon hann aldrig heller att få något stöd av de lagar som tillkom mellan åren 19181920 och som något förbättrade förhållandena för ensamstående mödrar och deras barn. Historikern Helena Bergman (2003) har skrivit en doktorsavhandling om barnavårdsmannainstitutionens förhistoria, födelse och blomning. Bakgrunden är en oro för de ensamstående mödrarnas situation. Det var inom fattigvårdsfolket, dvs. de socialliberala socialreformatorer som samlades inom Centralförbundet för Socialt Arbete (CSA) och Svenska fattigvårdsförbundet, som problemen för de ogifta mödrarna och deras barn först artikulerades. Förbunden ordnade flera möten och kongresser om frågan. Det förekom också upprop till regeringen om förbättringar för de növergivna mödrarna» och krav på att samhället borde ställa större krav på de barnafäder 
som undandrog sig ett ansvar mot de barn de satt till världen. Genom att fostra kvinnorna till goda mödrar kunde man uppnå stora samhällsvinster av ekonomisk, social och befolkningsmässig art. Att rädda ogifta kvinnor till moderskapet ansågs fylla en viktig samhällsfunktion (Bergman 2003).

På rymmen från ett fosterhem får Martin kontakt med barnavårdsnämnden och får övernatta i en poliscell innan han förs till ett barnhem. Barnavårdsnämnder och barnavårdslagar var vid denna tid nya företeelser. Den första barnavårdslagen i Sverige hade trätt i kraft 1903. De barnavårdslagar som tillkom i Norge, Sverige och Danmark vid sekelskiftet var likartade. Vanartade barn och barn som var försummade $i$ hemmet skulle i varje kommun övervakas av en nämnd som kunde förmana barn och föräldrar, upphäva föräldramyndigheten, omhänderta barn från hemmet och placera dem i fosterhem, barnhem, skolhem, skyddshem osv. Det banbrytande med lagarna var synen på unga lagbrytare. I stället för att straffas skulle de fostras. Barnen behövde inte ha begått lagbrott eller vara vanartade för att bli omhändertagna. Moraliskt förfall i hemmet eller föräldrarnas försummelse var tillräckligt för insatser. Övergivna barn som romanfiguren Martin rönte alltså uppmärksamhet i samhällsdebatten. En annan fråga är i vilken mån diskussionen nådde ut $\mathrm{i}$ landet och om intresset omsattes i praktisk handling.

\section{Mellan retorik och praktik}

I samhällsdebatten ville man förbättra barnens och andra utsattas förhållanden, men i praktiken såg det förmodligen helt annor- lunda ut för barn som Martin som var hänvisade till fattigvårdens hjälp och stöd i små landsortskommuner. En otydlig fattigvårdslagstiftning som gav den enskilde ett mycket svagt stöd gjorde att Martin upplevde att ingen lyssnade på honom. Även om många i samhällsdiskussionen menade att Bolle skulle behandlas med frivillighet i stället för tvång, såg det nog helt annorlunda ut $\mathrm{i}$ praktiken i de landsortskommuner där han luffade runt. Anne-Lise Seip (1984) talar om socialhjälpsstaten. Medborgarnas möjligheter till hjälp från samhällets sida under de första decennierna under 1900-talet var mycket begränsade och någon generell välfärdspolitik fanns knappast inte. Man var hänvisad till fattigvårdens individuella behovsprövning. Debatten handlade förmodligen mer om ambitioner än realiteter.

Martin bodde i en liten kommun i Blekinge. När man diskuterade barnens situation i samhället vid denna tid hänvisades ofta till storstäderna. Det var här pressen fanns och det var här filantroper och räddningsrörelse hade sin starka ställning. Det var svårt att uttrycka en landsomfattande opinion, tidningarna hade små upplagar och de spreds många gånger inte utanför storstäderna. De sociala tidskrifterna, t.ex. Social Tidskrift som hade startat 1901, lästes förmodligen mest av en urban och bildad medelklass som redan var reformanhängare. Statsvetaren Lennart Lundquist (1997) skriver om en grupp i Sverige, nämligen fattigvårdsfolket, som årtiondena efter förra sekelskiftet ville åstadkomma förbättringar på det sociala området. Det var en grupp som verkade i Stockholm och fick ett stort genomslag i debatten. I de små kommunerna fanns förmodligen inte 
denna reformiver och debatt. Det fanns förmodligen inte heller i fattigvårds- och barnavårdsnämnderna ute $i$ landet någon fackkunskap om utsatta människors behov. Åren omkring förra sekelskiftet hade några socialarbetarutbildningar startat ute i världen. Socialt arbete hade tidigare varit ett kall som drevs av outbildade utan ersättning. $\mathrm{Nu}$ ville man göra det till ett yrke. Roy Lubove (1965) förlägger, i boken The Professional Altruist. The Emergence of Social Work as a Career 1880-1930, uppkomsten till femtio år runt förra sekelskiftet. Han syftar då på övergången från social verksamhet som ett väsentligen oavlönat, filantropiskt företag till ett avlönat yrke med fackutbildning som grund. I Sverige är det kanske mer vanligt att man förlägger denna övergång till en bra bit in på 1900talet. Representanter för fattigvårdsfolket i Sverige följde utvecklingen internationellt och ville starta liknande utbildningar här, men möttes fram till 1921 av motstånd från kommuner och statsmakt. Först 1921 tillkom den första socialarbetarutbildningen i landet. Det var dock först i och med det socialdemokratiska regeringsprogrammet 1932 som utbyggnaden av välfärden planerades på allvar och kunde senare verkställas efter andra världskriget. Det var också under den socialdemokratiska regimen som socialarbetarutbildningarna byggdes ut och förstatligades och utbildade socialarbetare i större utsträckning började anställas i de genom kommunsammanslagningar växande kommunerna. Då började det också bli lite mer vanligt att barn och utsatta mötte en utbildad socialarbetare istället för förtroendemän i de kommunala nämnderna (Kollind 2003).
Även om frågorna om hur man bättre skulle förstå och hjälpa utsatta människor under 1900-talets båda första decennier diskuterades var det långt mellan retorik och praktik. Huvudstadens diskussioner om behovet av sociala reformer hjälpte inte Martin och Bolle särskilt mycket, och det är inte ens säkert att de hade hört talas om dem.

\section{Vad kan vi lära oss?}

Med hjälp av Martinsons romanfigurer Martin och Bolle har jag gjort några nedslag i vår socialhistoria och i den välfärdshistoriska forskningen. Det finns en omfattande forskning om de frågor och dilemman som aktualiseras i romanerna och jag tror att romanfigurerna kan fungera som guider för att förstå människor och sociala problem på ett mer mångfasetterat sätt. Låt mig ta Bolle som konkret exempel på hur jag menar. En av de mest kända samhällsvetenskapliga luffarstudierna som fortfarande citeras flitigt är Nels Andersons (1975) The American Hobo som ursprungligen publicerades 1923. Anderson tillhörde Chicagoskolan och gjorde observationer i Chicagos slumområden. Innan han började läsa sociologi var han uppväxt i en familj som till stora delar var kringresande hobos. Oscar Andersson (2003) som studerat Chicagoskolans idétradition menar att studien var ett sätt för Anderson att göra upp med sitt förflutna och gå vidare i livet. Ett centralt vetenskapligt problem för Chicagoskolan var transittillstånden, dvs. en övergångsfas mellan olika livsvärldar (Jfr. Järvinen 2003; Park 1967). Styrkan med Andersons studie menade många var att han själv var en 
person i transittillstånd, dvs. på väg mellan olika sociala världar. Han kunde både med vetenskapliga metoder och egna upplevelser gestalta detta tillstånd från en rad olika perspektiv, även om det också finns stora risker med sådana angreppssätt. Parallellerna med Martinsons liv är uppenbara. Han hade erfarenheter av luffar- och hemlöshetslivet och han befann sig i ett transittillstånd när han skrev sina böcker. Kanske ville han som Nels Anderson göra upp med sitt förflutna. I vilket fall som helst kan han med egna erfarenheter som grund gestalta och pedagogiskt levandegöra hur det är att vara utsatt, hemlös och tiggare. Martinson levandegör en djup smärta hos romanfigurerna, något som de vetenskapliga texterna ofta har svårt att beskriva. Att läsa forskningstexter och skönlitterära texter om hemlösa vid sidan av varandra kan ge viktig information och berika forskarnas kunskaper. Dessutom är forskning om transittillstånd (även om vi inte kallar det så i dag) fortfarande en central fråga. I dagens hemlöshetsforskning analyseras hur gränser uppstår, hur moderna härbärgen motiveras som övergångsinstitutioner och hur de sociala mekanismer ser ut som skapar beständig ojämlikhet. Hur vi skall förstå att en del människor lämnar livet på samhällets botten och skapar en annan tillvaro, medan andra blir kvar i ett livslångt utanförskap är andra centrala samhällsvetenskapliga frågor.
Så visst finns det skäl för dagens forskare att läsa Martinson. Men kan man då lita på att de litterära beskrivningarna är riktiga och återspeglar faktiska förhållanden? En del av Martinsons levnadstecknare har pekat på att han har haft fel i detaljer när han beskrivit svensk fattigvård vid förra sekelskiftet. Sonja Erfurth (1980) ifrågasätter t.ex. det klubbslag som beskrivs när syskonen auktionerades bort som sockenbarn till lägstbjudande. Det bör istället ha varit fråga om ett beslut i fattigvårdsstyrelsen och någon form av social utredning. Även om det i detaljer inte gick till som Martinson beskriver finns det ingen anledning att betvivla hans beskrivningar av hur Martin och Bolle upplevde de åtgärder de blev utsatta för. Många fosterbarn från denna tid har berättat om kärlekslösheten och att de fick slita hårt i fosterhemmen. Forskarna vid Tema barn i Linköping har i flera avhandlingar och skrifter belyst situationen för de barn i början av 1900-talet som uppfostrades utom hemmet (se t.ex. Sundkvist 1994). Vi vet också att det riktades en omfattande kritik mot den gamla fattigvårdslagstiftningen och hur den hanterades ute i de små fattiga kommunerna.

Martinson har kanske mer än någon annan svensk författare skildrat fattig-Sverige inifrån och från den lilla människans perspektiv. Det är kunskaper som inte skall underskattas av dagens samhällsforskare. 


\section{Referenser}

Alfvén, Andrew (1913) „Ungkarlshotell och natthärbärgen i Stockholm. Några av huvudstadens förnämsta pästhärdar", Social Tidskrift 3:97126.

Anderson, Nels (1975) The American Hobo, E. J. Brill, Leiden, Netherlands.(Originalutgåvan publicerat 1923) The Hobo. The Sociology of the Homeless Man, Chicago: University of Chicago Press.

Andersson, Oscar (2003) Chicagoskolan. Institutionaliseringen, idétraditionen och vetenskapen. Lund Monographs in social antropology 11.

Bergman, Helena (2003) Att fostra till föräldraskap. Barnavårdsmän, genuspolitik och välfärdsstat 1900-1959. Stockholm: Acta Universitatis Stockholmiensis, Stockholom Studies in History. Björkman, Jenny (2001) Vård för samhällets bästa. Debatten om tvångsvård $i$ svensk lagstiftning 1850-1970, Stockholm: Carlssons.

Edebalk, Per Gunnar (203) „Folkpension och åldringsvård - om svensk socialpolitik 1903-1950《 i Socialvetenskaplig Tidskrift nr 2-3, s. 131-150.

Edman, Johan (2004) Torken. Tvångsvård av alkoholmissbrukare i Sverige 1940-1981. Stockholm: Acta Universitatis Stockholmiensis.

Erfurth, Sonja (1980) Harry Martinsons barndomsvärld, Stockholm: Bonniers förlag.

Erfurth, Sonja (1991) Harry Martinson och vägen $u t$, Stockholm: Bonniers förlag.

Flaskan och drinkarens barn i 16 tavlor, tecknade och etsade av Cruishank (1907), Lund: Ph. Lindsteds Universitetsbokhandel.

Förhammar, Staffan (2000) bok Med känsla eller förnuft? Svensk debatt om filantropi 1870-1914, Stockholm: Almqvist \& Wiksell International

Gordon, Linda (1989) Heroes of their own lives. The politics and history of family violence, London: Virago press.

Gyllensten, Lars (2000) Minnen, bara minnen, Stockholm: Bonniers förlag.

Hedin, Marika (2002) Ett liberalt dilemma: Ernst Beckman, Emilia Brommé, C H von Koch och den sociala frägan 1880-1930, Stockholm/ Stehag: Symposion.
Himmelfarb, Gertrude (1984) The Idea of Poverty. London: Faber.

Hopper Kim (1987) A Bed for the Night: Homeless Men in New York City, Past and Present, Doctoral dissertation, Columbia universitet.

Hopper, Kim (1990) „Public Shelter as 'a Hybrid Institution': Homeless men in Historical Perspective", Journal of Social Issues (46) 4:13-29.

Hopper, Kim (1991) "A Poor Apart: The Distancing of Homeless Men in New York's History", Social Research (58)1 Spring:107-132.

Hopper, Kim (1992) „Marginalia: Notes on Homelessness in the United States", Hemlöshet i Norden (red. Margaretha Järvinen, \& Christoffer Tigerstedt), Helsingfors: NAD-publikation 22.

Jansdotter, Anna (2004) Ansikte mot ansikte. Räddningsarbete bland prostituerade kvinnor $i$ Sverige 1850-1920, Stockholm/Stehag: Symposion.

Järvinen, Margareta (2003) »Mellan patologisering och romantisering - utdrag ur hemlöshetsforskningens historia巛 i Den ocensurerade verkligheten $i$ reportage, bild och undersökningar (red. Anna Meeuwisse \& Hans Swärd), Stockholm: Carlssons).

Key, Ellen (1900) Barnets århundrade, Stockholm: Bonniers förlag.

Kollind, Anna-Karin (2003) »Kvinnor och socialt arbete - vid övergången från filantropi till profession" I Socialvetenskaplig Tidskrift nr 2-3, s.172-192.

Levin, Claes (1998) Uppfostringsanstalten. Om tvång I föräldrars ställe. Lund: Arkiv.

Lubove, Roy (1965) The Professional Altruist. The Emergence of Social Work as a Career, Cambridge, Massachusetts: Harvard University Press.

Lundgren, Frans (2003) Den isolerade medborgaren. Liberalt styre och uppkomsten av det sociala vid 1800-talets mitt, Gidlunds förlag: Hedemora.

Lundquist, Lennart (1997) Fattigvårdsfolket : ett nätverk $i$ den sociala frågan 1900-1920, Lund: Lund University Press.

Lundström, Tommy (1993) Tvångsomhänderta-

Hans Swärd: Vad kan vi lära av Harry Martinsons författarskap? 
gande av barn. En studie av lagarna, professionerna och praktiken under 1900-talet. Rapport Socialt arbete $\mathrm{nr}$ 61, Stockholms Universitet, Socialhögskolan.

Martinson, Harry (2004) Nässlorna blomma, Stockholm: Bonniers förlag.

Martinson, Harry (2001) Vägen ut, Stockholm: Bonniers förlag.

Martinson, Harry (1949) Vägen till Klockrike, Stockholm: Bonniers förlag.

Park, Robert E. (1925/1967) "The Mind of the Hobo: Reflections upon the Relation Between Mentality and Locomotion" I Park, R.E. m.fl. The City. Chicago: The University of Chicago Press s. 156-160.

Riis, Jacob August (1890) How the Other Half Lives, New York: Charles Scribner's sons.

Ross, D G (1972) Stanley Hall. Te Psychologist as Prophet, Chicago/London.

Seip, Anne-Lise (1984) Sosialhjelpstaten blir til: norsk sosialpolitikk 1740-1920, Oslo: Gyldendal.

SFS 1918:422§2

Simmel, George (1995) „Främligen« s 139-145, i Hur är samhället möjligt?- och andra essäer. Göteborg, Korpen. (Original publicerat 1908).

Sjögren, Mikael (1997) Fattigvård och folkuppfostran. Liberal fattiguairdspolitik 1903-1918. Stockholm: Carlssons.

Social Tidskrift 1901-1917.
Socialvetenskaplig tidskrift (2004) nr 2-3. Tema Svensk välfärd under 100 år.

Steinmetz, G (1993) Regulating the social. Princeton, NJ: Princeton University Press.

Sundkvist, Maria (1994) De vanartade barnen. Mötet mellan barn, föräldrar och Norrköpings barnavårdsnämnd 1903-1925, Linköping: Hjelms.

Swärd, Hans (1998) Hemlöshet. Fattigdomsbevis eller välfärdsdilemma? Lund:Studentlitteratur.

Swärd, Hans (2001) »Porträtterad nöd - berättelser om hemlösa» i Socialvetenskaplig tidskrift nr 122001 s. 54-76.

Tagg, John (1988) The Burden of Representation. Essays on Photographies and Histories. London: Macmillan.

Tengdahl, Knut A. (1897) Material till bedömande af hamnarbetarnes $i$ Stockholm Lefnadsförhållanden, Stockholm: Skrifter utgifna av Lorénska stiftelsen nr 13.

\section{Tvärsnitt 2004}

Wisselgren, Per (2003) „Det sociala reportaget - journalistik, litteratur eller vetenskap? i Den ocensurerade verkligheten i reportage, bild och undersökningar (red. Anna Meeuwisse \& Hans Swärd), Stockholm: Carlssons.

Åmark, Klas (2004) „Trygghet och tvång - två teman i aktuell nordisk välfärdsstatshistorisk forskning« i Arkiv, nr 91, 2004 s. 1-18.

\section{Länkar:}

http://www.harrymartinson.org/biograph.htm http://www.lysator.liu.se/runeberg/authors/hmartins.htm 


\section{Summary}

\section{What can we learn from the works of Martinson?}

This year marks the centennial of the birth of the Swedish author Harry Martinson, an event which has been celebrated all over the country. The research field of social science also has cause to consider Martinson. Perhaps more than any other Swedish writer, he has portrayed early twentieth-century Swedish poverty. Based on his own experience, but with the licence of the poet, Martinson has shed light on the conditions of people who came into contact with the system of public relief and control in bygone Sweden. He had a unique career, proceeding from workhouse inmate to member of the Swedish Academy and Nobel laureate in literature.

In the article we follow two characters from two novels during the decades after 1900: the abandoned child Martin, who is boarded in different foster-homes and experiences the lack of love and interest shown by adults, and Bolle the tramp. With their aid we look at aspects of social history and research on the subject. 